\title{
Therapeutic gamma delta T-lymphocytes
}

National Cancer Institute

\section{Source}

National Cancer Institute. Therapeutic gamma delta T-lymphocytes. NCI Thesaurus. Code C124644.

A subset of therapeutic autologous T-lymphocytes that express a T-cell receptor (TCR) composed of one gamma chain and one delta chain, with potential immunomodulating and antineoplastic activities. Upon administration of the therapeutic gamma delta Tlymphocytes, these cells secrete interferon-gamma (IFN-g), and exert direct killing of tumor cells. In addition, these cells activate the immune system to exert a cytotoxic Tlymphocyte $(C T L)$ response against tumor cells. Gamma delta T-lymphocytes play a key role in the activation of the immune system and do not require major histocompatibility complex (MHC)-mediated antigen presentation to exert their cytotoxic effect. 